Matusz Márk Péter ${ }^{1}$

\title{
A Magyar Honvédség csapategészségügyének telemedicinális fejlesztési lehetőségei
}

\section{Developing Possibilities of the Telemedicine in the Hungarian Defence Forces' Military Healthcare}

\begin{abstract}
Absztrakt
A cikkben ismertetem a hazai civil egészségügyi ellátó intézményekben használt föbb telemedicinális eszközöket. Azonositom és megnevezem a müködtetésük során szerzett elsődleges tapasztalatokat. Ezen gyakorlati ismeretek felhasználásával összeállítom és bemutatom a Magyar Honvédség egészségügyi szolgálatánál bevezetésre javasolt telemedicinális koncepciót. Végül a megtervezett telemedicinális rendszer potenciális elönyeit és rizikófaktorait is azonositom.
\end{abstract}

Kulcsszavak: egészségügyi ellátás, telemedicinális rendszer, telefonos applikáció

\section{Abstract}

In the article the main telemedicine means will be described that are being used in the civilian healthcare institutes. The primary experiences of the system will be identified and specified. Based on this practical knowledge the suggested to-be-introduced telemedicine conception for the Hungarian Defence Forces' military healthcare system will be framed and presented. Finally the potencial advantages and risk factors of the designed telemedicine system will be identified.

Keywords: healthcare system, telemedicine system, mobilephone application 


\section{Bevezetés}

A 2019-es esztendőben Magyarországon egyre inkább elkerülhetetlen, hogy szembenézzünk a kialakult orvos-, szakorvoshiánnyal. ${ }^{2}$ A kedvezőtlen munkaerőpiaci folyamat a Magyar Honvédség orvosállományát is érinti, sőt a jelenség az orvosutánpótlás számának csökkenésében is markánsan tetten érhetö. A 2017-es állapothoz képest, amikor az alakulatok orvosbeosztásai körülbelül fele volt feltöltetlen ${ }^{3}$, a helyzet tovább romlott: az alakulatoknál ma már elvétve találkozunk csak katonaorvossal. A helyzet nem egyedi, más NATO-tagország is küzd hasonló gondokkal. ${ }^{4}$

A feltöltetlen orvosbeosztásokat részmunkaidős honvédelmi alkalmazott jogviszonyban állókkal, illetve éves beszerzés keretében, pályázati úton próbálja kiegyensúlyozni a rendszer. A kialakult helyzet kezd kritikus méreteket ölteni: a betegellátáson kívül, az egyre növekvő feladatok a megmaradt szakembergárdára hárulnak. Az egy orvosra jutó feladatrendszert és a napi betegellátási számot racionalizálni kell, különben a túlterheltség következtében az orvoslétszám további apadása folytatódni fog. Az orvosok leterheltségének csökkentése, illetve a jelenlegi helyzet megoldása érdekében, célirányos, áthidaló, racionalizáló megoldások mielőbbi kifejlesztése, és gyakorlati alkalmazása szükséges.

Felmerül a kérdés, hogy az elkövetkező időszak fejlesztései és a végrehajtott létszámbővítést követően a jelenlegi orvos állomány jelenlegi eszközrendszerével és létszámából adódóan képes lesz-e a szükséges egészségügyi feladatok végrehajtására? Jelen feltételrendszerrel kizárólag a sürgősségi ellátás végrehajtására kell fókuszálni, vagy törekedni kell a napi betegellátás spektrumának lehetőség szerinti bővítésére is? Milyen események várhatóak a jövőben, amelyekre a katonaegészségügynek reagálnia kell, és ezek kapcsán milyen intézkedéseket kell tudnia meghozni? A prevenció és a diagnosztika fejlesztésével hol érhető el mérhető hatékonyságjavulás a betegellátásnál? Milyen képességekkel kell rendelkezni a csapategészségügynek az új kihívások tükrében az állomány egészségi állapotának megóvása, illetve védelme érdekében?

Ebben a kutatásban célul tűztem ki, hogy a fenti kérdések megválaszolásával olyan javaslatokat dolgozok ki, amelyek megvalósítása esetén azok hatékonyabbá tehetik a csapategészségügyi ellátást, és egyúttal az orvosok leterheltségét és ennek következtében kiválásának mértékét is csökkentik. A tanulmányom további célja azon orvosi szakterületek beazonosítása, amelyekre már kipróbált, müködő telemedicinát használó eszközrendszereket fejlesztettek ki, és ennek következtében a csapategészségügyi ellátórendszerbe - potenciális előnyeiket kihasználva - zökkenőmentesen beilleszthetővé válnak.

Jasztrab Jácint Szilárd: A katonaorvosi pályaválasztás és pályaelhagyás motivációi. Honvédségi Szemle, 146. (2018), 2. 101-113.

Baranyai Gábor: Ösztöndijjal enyhítik a katonaorvos-hiányt. Magyar Idők, 2017.

Jasztrab (2018) i. m. 111. 


\section{A kutatás és az alkalmazott módszerek leírása}

A kutatásom során elsősorban az analízis módszerével elemeztem a vonatkozó elektronikus és a nyomtatott hazai szak- és tudományos irodalmakat. Másodsorban lehetőségem adódott az egészségügy területén dolgozó szakemberekkel struktúrálatlan interjúk készítésére.

\section{Telemedicinát használó eszközökröl készült beszámolók a hazai tudományos kutatásokban}

Mielőtt még a vonatkozó szakirodalmak áttekintését megkezdem, szükségesnek tartom a telemedicina jelenségét röviden áttekinteni.

A telemedicinát egyik legtalálóbb definíciója alapján, olyan strukturált egészségügyi szolgáltatásként lehet jellemezni, ahol az ellátásban részesülő és az ellátott személy közvetlenül nem találkozik, a kapcsolat valamilyen távoli adatátviteli rendszeren keresztül jön létre. ${ }^{5}$ Ezt a lényegre törő definíciót talán azzal lehetne kiegészíteni, hogy felsoroljuk a kapcsolat lehetséges fajtáit: ${ }^{6}$

1. Távkonzilium/szupervízió: ahol a diagnózis kialakításába, a kezelés menetébe kommunikációs eszközökön keresztül távoli orvos/szakszemélyzet is be van vonva.

2. Távdiagnosztika: amikor a diagnózis alapját adó vizsgálat végzője és a diagnózis felállítója (a lelet készítője) térben elválik egymástól, de interaktív kapcsolatban vannak.

3. Távfelügyelet/telemonitoring: amikor az egészségügyi szakszemélyzet jelenlétét a betegnél levő/őt figyelő jelfogók (detektorok) és jeltovábbítók pótolják.

4. Távmanipuláció: amikor a vizsgálatot vagy beavatkozást végző személy távérzékelőkre támaszkodva távolról vezérli (végzi) az interakciót igénylő vizsgálatot (például endoszkópia) vagy beavatkozást (például videóvezérlés mellett robottal vagy távvezérlésre alkalmas eszközzel végzett távmanipuláció).

Adódik a kérdés, miért jó, miért hasznos ez a megoldás, mik a kézzel fogható előnyei? Az alább idézett tudományos kutatások rövid összefoglalásával próbálok válaszolni a kérdésre.

Az elmúlt időszak elemzései bebizonyították, hogy a telemedicina fejlődése és népszerüsége töretlen, a 2018-as esztendőben a technológiai újitásokban gyakran élenjáró Amerikai Egyesült Államokban hozzávetőlegesen 7 millióan vették igénybe valamelyik szolgáltatását és az elkövetkező években a telemedicinát használók tábora hozzávetőleges becslések alapján, évente 14,3\%-kal növekedni fog. ${ }^{7}$ Vélelmezhetően, a fent részletezett potenciális előnyök megtapasztalásán felbuzdulva további sikeres orvostechnikai eszközök, megoldások fognak születni, amelyek további bővülést fognak generálni.

Fejes Zsolt: Új lehetőség a védelem-egészségügyi ellátásban: Telemedicina. Hadmérnök, 11. (2016), 1. 233-239.

Állami Egészségügyi Ellátóközpont: Telemedicina. Egészségtudományi fogalomtár, é. $\mathrm{n}$.

www.beckershospitalreview.com/healthcare-information-tecnology/telemedicine-to-attract-7m-patient-users-by-

2018-12-statistics-on-the-thriving-market.html 
A telemedicina témájában, az általam vizsgált kutatások nagy része 2005 után keletkezett, és olyan témákat elemez, amelyek a tanulmány(ok) megírásakor aktuálisak voltak, és napjainkban is tudunk belőlük általános érvényü megállapításokat meríteni. A témában megjelent nagy mennyiségű publikáció feldolgozásából az alábbi áttekintésben kizárólag arra merek vállalkozni, hogy egyes fontosabb megállapításokat és kulcsgondolatokat megemlítek, amelyekre a jelen elemzésemet építem.

A telemedicinával foglalkozó kutatások áttekintése után megállapítható, hogy az egyik legnépszerủbb és leginkább közérthető, elérhető területe a telekardiológia. Kiss István és Kékes Ede összefoglaló közleményükben megállapították, hogy a telekardiológiai eszközrendszer önmagában nem elégséges további hatékonyság növelésére. Arra a következtetésre jutottak, hogy a személyes kapcsolat fenntartása és az interaktív távmonitorozás lehetősége együtt adja a hypertoniás betegeknél a célvérnyomás eléréséhez és a kívánt vérnyomásérték fenntartásához szükséges támogatást. ${ }^{8}$ Bán Attila tudományos közleményében rámutat, hogy Magyarországon európai viszonylatban is magas az akut miokardiális infarktusos megbetegedések száma, így különösen indokoltnak tartja a háziorvosi praxisban a telekardiológiai eszközök használatát. Tanulmányában összefoglalta, hogy a telekardiológiai szolgáltatás a páciens minőségi ellátását támogatja, és kijelenti, hogy az eszköznek (transztelefonikus EKG) már a megelőzésben is szerepe kell hogy legyen. ${ }^{9}$

A Magyarországon a teleradiológia megjelenését és térhódítását, valamint az ebből adódó jelentőségét Dr. Bágyi Péter és Mohai Viktor közleményének kezdetéből pontosan megérthetjük: „Egy egészségügyi intézmény tevékenysége során a képalkotó diagnosztika alapvető funkció, mely nagymértékben hozzájárul az intézmény gazdaságos és fenntartható működéséhez."10 A közleményükben a szerzők rámutatnak az informatikai háttér fejlesztésének szükségességére, és megállapították, hogy jelenleg a teleradiológia különféle szabványosított technikai megoldások segítségével világszerte használatos. Rávilágítottak a radiológus szakemberek a modalitásproblémára, azaz nem minden radiológus ért mind a négy általuk felsorolt területhez (ultrahang, RTG, CT, MR), valamint megjegyezték, hogy a radiológus szakembereknél is megfigyelhetö a szervspecifikáció jelensége. Értekezésükben bemutatták a TeleXray projektet, amely a röntgendiagnosztikai területen várható kapacitáshiány leküzdésére hivatott. Elönyként számoltak be, hogy az igény oldalról esélyegyenlőséget tud a fejlesztés biztosítani, a radiológuskapacitást hatékonyabban kihasználja, és a rendszer magában foglalja a szupervízió lehetőségét is. Az általuk bemutatott rendszerben a leletmegfordulási idő átlag 30 percre csökkent. ${ }^{11}$ Prof. Dr. Bogner Péter és Bágyi Péter tanulmányukban rámutatnak, hogy a radiológiai képalkotó diagnosztikai képszám évente mintegy 15\%-kal nő, és ezt a radiológus képzés nem tudja követni. Közleményükben nyomatékosítják a megfelelő informatikai háttér meglétének fontosságát, amelyet egy CT-/MR-lelet nagyságával szemléltetnek, ami akár $1 \mathrm{~Gb}$ is lehet. A tanulmány további fontos üzenete,

8 Kiss István - Kékes Ede: A hypertóniás betegek célvérnyomás-elérési arányának és gondozási minőségének segítése telemedicinális lehetöségek alkalmazásával. 245.

9 Bán Attila: A telemedicina potenciális szerepe a háziorvosi ellátás hozzáférhetőségének és minőségének javitásában. Magyar Tudományos Akadémia, Közgazdaság- és Regionális Tudományi Kutatóközpont, é. n. 185-186.

10 Bágyi Péter - Mohai Viktor: (Táv)leletezés és munkamenedzsment. Interdiszciplináris Magyar Egészségügy, 13. (2014), 6. 52.

11 Bogner Péter - Bágyi Péter: A teleradiológia alkalmazása hazánkban. Magyar Orvos, (2009), 10. 43-46. 
hogy a szerzők véleménye alapján javasolják a klinikusok és a radiológiai szakorvosok közötti kommunikáció erősítését. Kijelentik, hogy a leletezés végrehajtása a betegről a teljes klinikai információ birtokában kell hogy megtörténjen.12

A teledermatológia gyakorlati alkalmazhatóságáról Danis Judit, Forczek Erzsébet és Bari Ferenc összefoglaló közleményében megállapította, hogy mivel a bör elváltozásai könnyen dokumentálhatók fényképezőgéppel, így telekommunikációs eszközrendszert használva, távellátással is megfelelő diagnózist lehet felállítani. A tanulmányban megemlítették, hogy Magyarországon a telemedicina ezen területe még nem honosodott meg, pedig a betegellátást hatékonyabbá, gyorsabbá és olcsóbbá tehetné. A közleményben meghatározták, hogy a diagnózis megbízhatósága a konzultáció alapelvétől, a vizsgált bőrelváltozás típusától és a készített képek minőségétől függ. Kijelentették, hogy a teledermatológiai diagnózisok megbízhatósága (azaz, hogy két vagy több vizsgáló által megállapított diagnózis azonos lesz) megközelíti a személyes konzultáció megbízhatóságát. A közleményben a szerzők megállapítják, hogy a szakorvosi leterheltség tényleges könnyítése érdekében a távkonzultáció kiépítésére és a szakszemélyzet kiképzésére lesz szükség. ${ }^{13}$

Tóth Anikó Panna közleményében összefoglalja az infokommunikációs csatornákon történő pszichológiai ellátás lehetőségeit. Tele-mentálhigiénének nevezi el, utalva arra a tényre, hogy Magyarországon általánosan elfogadott megnevezés még nincs használatban. Rámutat, hogy a telemedicina ezen területe Magyarországon nem fejlett, de a szektorban dinamikus fejlödési potenciált lát. A szenvedélybetegek és a különböző mentális betegségek magas száma ellenére alacsony számú a regisztrált segítségkérés, amit az ellátórendszer hiányával és kulturális okokkal magyaráz. Kijelenti, hogy az online pszichológiai kezelések ma már bizonyítottan hatékonyak, a hatékonyság mérésére szempontrendszert fejlesztettek ki. Rámutat, hogy az Európai Unió is támogatja a telemedicina fejlesztését. A szerző külföldi példákkal szemben viszont Magyarországon hiányolja a kiadott ajánlásokat, vonatkozó szabályzókat. A felhasználási lehetőségek részletezésénél kiemeli, hogy a technológia használatával olyan periférián lévő csoportok megszólítása válik lehetővé, akik eddig igen nehezen voltak elérhetőek. A tanulmány összefoglalásában javasolja, hogy a tele-mentálhigiéné területén az eddigi tapasztalatokat gyüjtsék össze, hogy a potenciális lehetőségek és veszélyek fajtáit beazonosithassák. További fontos javaslat, megállapítás a szerző részéről, hogy a területben rejlő potenciált az itt dolgozó szakemberek könnyebben felismerik, amennyiben a képzésekben az infokommunikációs technológiák ismereteit fejlesztik. ${ }^{14}$

Ebben a fejezetben a jelenleg Magyarországon elérhető és működtetett telemedicinális eszközökröl készült áttekintés. Kizárólag azon megoldásokat mutatom be, amelyek a Magyar Honvédség csapategészségügyi szintjén is hatékonyan tudnák segíteni az ellátást. Összefoglalásként megállapítom, hogy a bemutatott orvostechnikai eszközök működtetésével már rövid távon is számos kézzelfogható előnyre tehetne szert a csapategészségügyi ellátó rendszer:

12 Danis Judit - Forczek Erzsébet - Bari Ferenc: A telemedicina alkalmazása a bőrgyógyászatban: a teledermatológia. Orvosi Hetilap, 157. (2016), 10. 363-369.

13 Tóth Anikó Panna: A mentálhigiéné fejlesztési lehetőségei a telemedicina segítségével. Metszetek, 6. (2017), 2. $139-166$.

14 24/2005. (VI. 30.) HM rendelet a Magyar Honvédség Szolgálati Szabályzatának kiadásáról. 
- A beteg részéről az orvosi szolgáltatás (tanácsadás, de akár diagnózis) gyorsabb elérése.

- Az egészségügyi ellátás hatékonysága növekszik (célirányos folyamat, nincs várakozás, nincs utazással töltött idő).

- Szükség esetén, folyamatos (0-24 h) monitorozása a beteg egészségügyi állapotának, anomália esetén adott az akár azonnali beavatkozás lehetősége.

- Prevenció és kontroll hatékonyabb tervezése és végrehajtása.

- A rendszerbe bekapcsolódott személyek egészségtudatos hozzáállásának fejlesztési lehetősége.

\section{Tervezett telemedicinális eszközök}

Fontosnak tartom kiemelni, hogy a fejezetben bemutatandó telemedicinális eszközök rendszere elsődlegesen béke egészségügyi ellátásra lett megtervezve. Aktív, folyamatban lévő háborús szerepvállalással, a honi egészségügyi ellátás biztosítását egy új súlyozási rendszer alapján kell megvizsgálni, ami jelen közleményemnek nem célja.

Mielőtt belekezdek a koncepcióm felvázolásába, szükségesnek tartom a Szolgálati Szabályzat idevonatkozó pontjainak ismertetését, ami tulajdonképpen a felhatalmazást adja a bemutatandó képességfejlesztési lehetőségre. Az alakulatoknál az egészségügyi központ parancsnokának feladatrendszerét, a katonák ellátásának alapelveit, illetve a szolgálati tevékenység biztosítását a Szolgálati Szabályzat idevonatkozó pontjai kitűnően megfogalmazzák, aktualitásukból mit sem vesztettek:

„Az egységegészségügyi fönök (egészségügyiközpont-parancsnok)

101.2. Az egység egészségügyi fönök (egészségügyi központ parancsnok) felelős a katonai szervezet egészségügyi biztosításáért, a személyi állomány egészségi állapotáért, egészségügyi ellátásáért, egészségügyi adatainak védelméért, valamint egészségügyi szakfelszereléséért.

102. Az egység egészségügyi főnök (egészségügyi központ parancsnok) kötelességei:

a) szervezze és irányítsa a katonai szervezet egészségügyi (gyógyító-megelőző, gondozó, közegészségügyi-járványvédelmi és foglalkozás-egészségügyi) ellátását;

b) folyamatosan kísérje figyelemmel a személyi állomány egészségi állapotát;

c) ismerje a katonai szervezet egészségügyi helyzetét;

e) azonnal jelentsen szolgálati és szakmai elöljárójának minden olyan megbetegedést vagy egészséget veszélyeztető körülményt, amely a személyi állomány alkalmazhatóságát veszélyezteti és a katonai szervezet parancsnokának, vagy attól magasabb szintű szolgálati vagy szakmai elöljárójának intézkedését igényli;

l) szervezze és végezze az egészségvédelmi, egészséges életmódra nevelési, egészségfejlesztési és drogmegelőzési felvilágosító munkát;

A katonák ellátásának alapelvei

235.2. Minden katona jogosult a tisztálkodásra, egészségügyi ellátásra, egyben köteles - egészségének védelme, szolgálatképességének megőrzése, illetve helyreállítása céljából - napi rendszerességgel tisztálkodni, a tisztaságot fenntartani és magát a gyógyító-megelőző rendszabályoknak alávetni. 
236.1. Csapatoknál, oktatási intézményeknél kiképzési (munka-) napokon járóbeteg-rendelést kell tartani. A hirtelen megbetegedett vagy sérült katonákat azonnal a segélyhelyre, munkaidőn túl a területileg illetékes egészségügyi intézménybe kell küldeni (szállítani).

237.1. A személyi állomány egészségi állapotának és erőnlétének ellenőrzése céljából a szakutasításokban és intézkedésekben meghatározott időközönként szürővizsgálatot kell tartani.

260.1. b) a szükséges egészségügyi, munkabiztonsági és drogszűrő vizsgálatoknak magát alávetni." 15

A Szolgálati Szabályzat egészségügyi ellátásra vonatkozó pontjai egy további ciklikusan felvetődő kérdéskört is megválaszolnak: az egészségügyi ellátás csapatszinten gyógyító, megelőző, gondozó, foglalkozás-egészségügyi, közegészségügyi, járványügyi feladatokból áll. Ennek értelmében csapatszinten nem lehet kizárólag sürgősségi ellátás müködtetésében gondolkodni. A Szolgálati Szabályzat az egészségügyi ellátásra vonatkozó pontjai egyben iránymutatásként is szolgálnak.

Értelmezésem alapján, a kor aktuális kihívásainak megfelelően lehetőség, illetve felelősség a szabályzókat további hozzáadott tartalommal feltölteni. Következésképpen az egészségügyi ellátás müködtetése és fejlesztése érdekében kötelességnek tartom az orvosi rendelőket korunk elérhető, legmodernebb eszközrendszereivel felszerelni, és ezeket a szolgáltatásokat a magasabb szintü ellátás érdekében az állomány részére hozzáférhetővé tenni. Erre a lehető legkézenfekvőbb megoldás a civil ellátásban már kipróbált, bevált eszközrendszerek bevezetése és rendszeresítése. Ennélfogva csapategészségügyi szinten az egészségügyi központok felszerelését az alábbi telemedicínális eszközökkel, képességekkel javaslom bővíteni (1. ábra):

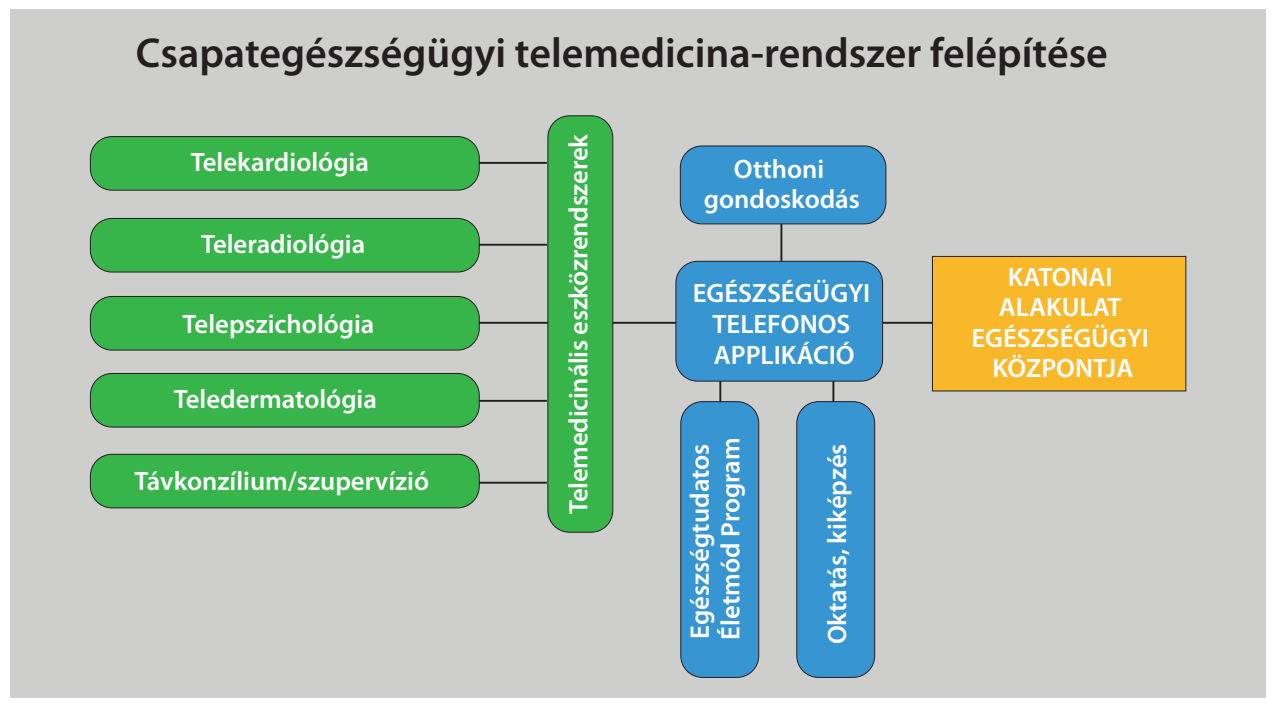

1. ábra: Csapategészségügyi telemedicina-rendszer felépítése

Forrás: a szerző szerkesztése

15 Központi Statisztikai Hivatal: 1.1. Népesség, népmozgalom (1900-) 3/3. 


\subsection{Telekardiológia}

A KSH 2017-es adatai alapján, a magyar lakosság körében a keringési rendszer betegségei vezetik a halálozási okokat, ${ }^{16}$ ennek okán javaslom a telemedicinális fejlesztések közül elsőként erre a betegségcsoportra fókuszálni. Csapatszinten a prevenciós tevékenység és a gondozással kapcsolatos feladatok két irányban valósulhatnának meg: telemedicinára alapuló 24 órás vérnyomásmérő, illetve EKG-készülék. Mind a két készülék indokolt esetben akár a beteg otthonába is kihelyezhető, kiterjesztve ezzel az egészségügyi állapot felügyeletét egy meghatározott időszakra. Az eszközök az orvos által naponta meghatározott alkalommal elvégzett mérések adatait az interneten keresztül elküldik egy erre a célra kialakított tárhelyre, amelyek online kontrollját munkaidő után, ügyeleti rendben, a Magyar Honvédség Egészségügyi Központ jelen helyzetben még nem létező telemedicinális képessége vehetné át.

Telemedicinális szívultrahang-készülék, amely munkaidőben, panasz esetén, illetve kontroll céljából csapatszinten végezné az előzetes vizsgálatot. A vizsgálat elvégzése után az adatok a Magyar Honvédség Egészségügyi Központba érkeznének be, kiértékelésük soron kívül történne. A kiértékelő kardiológus döntene a további lépésekről: „minden OK” nem igényel további vizsgálatot, további vizsgálatok és konzultáció szükséges, így időpont előjegyzése a Magyar Honvédség Egészségügyi Központ kardiológiai osztályán, illetve azonnali vagy sürgős beavatkozás esetén az Országos Mentőszolgálat értesítése.

\subsection{Teleradiológia}

Csapatszinten, a napi munkavégzési és kiképzési foglalkozások során elkerülhetetlen, hogy az állománynál ne történjen időnként rándulás, ficam, húzódás, részleges, teljes ín- vagy izomszakadás vagy akár csonttörés. Amennyiben a vizsgálathoz szükséges telemedicinát használó radiológiai eszközrendszer (röntgen és ultrahang) kiképzett egészségügyi személyzettel csapatszinten rendelkezésre állna, jelentősen csökkentenék a magasabb ellátó szintek leterheltségét. Kizárólag olyan esetben történne magasabb ellátási szintre szállítás, amikor a helyben történő vizsgálat alapján indokolt, vagy az eredménye nem egyértelmű. Hatalmas elörelépésnek tartanám, ha bizonyos esetekben már első körben csapatszinten, a helyi rendelőben megszülethetne a teleradiológiai szakorvosi támogatással alátámasztott diagnózis, ezzel is gyorsítva az ellátást és egyúttal csökkentve a Magyar Honvédség Egészségügyi Központba beutaltak számát.

\subsection{Telepszichiátria, -pszichológia}

Egy hangszigetelt szobával, hozzá a standardizált monitor- és videókamera-rendszerrel, megfelelő internetkapcsolattal kiegészítve, jelentősen növelni lehetne a pszichológiai,

16 David S. Gochman: Handbook of Health Behavior Research. NewYork, Plenum Press, 1997. 
pszichiátriai ellátáshoz való hozzáférést a Magyar Honvédség egész állománya részére. A kétirányú kamerás rendszer a széles sávú internetkapcsolat képességeit kihasználva, a földrajzi távolságok áthidalhatóvá válnak, akár terápiás foglalkozás is végezhetővé válik utazás és időveszteség nélkül. Értelemszerủen ez a pont két lépcsőt foglal magában: csapatszinten a teljes állománynak a pszichológusi szolgáltatás biztosítása, illetve a Magyar Honvédség Egészségügyi Központ szintjén a pszichológusi szolgáltatás pszichiátriai elérhetőséggel kibővítve állhatna rendelkezésre.

A képesség bevezetése több előnnyel is járna. Első körben a pszichológusi beosztással nem rendelkező missziók is bevonhatóvá válnak a pszichológusi ellátásba, ráadásul ezzel adott lenne a lehetőség, hogy a külszolgálaton lévő katona a saját alakulatánál lévő pszichológust válassza.

Másodsorban utazás okozta időveszteség nélkül olyan alakulatoknál is teljes pszichológiai ellátást lehetne biztosítani, mint a Magyar Honvédség Anyagellátó Raktárbázis, amely országosan 11 bázissal rendelkezik. Harmadrészben egy költségtakarékos és hatékony módja lenne az alakulatok közötti pszichológusi szupervízió és mentori rendszer kialakításának, katalizálva ezzel az egyéni szakmai fejlődést. Negyedrészben továbbgondolva a rendszert, egyéni elbírálás után akár a misszió utáni visszaszűrés is komfortosabbá és gyorsabbá válhatna.

\subsection{Teledermatológia}

A prevenciós koncepcióhoz tartozik, elsődlegesen a melanómaszürések bevezetésére és a hozzá tartozó rendszeres kontroll céljából illesztettem be a koncepcióba. Másodsorban a napi betegellátás során felmerülő bőrgyógyászt igénylő kérdésekben tudná az eszköz a támogatását kifejteni. Az eszköz müködési elvéről röviden elmondható, hogy jó minőségű digitális fényképezőkép analógiájára a meghatározott protokoll szerint fényképeket készít a kérdéses bőrterületről. A digitális fénykép(ek) et elektronikusan továbbküldené a kiértékelésre kijelölt bőrgyógyászhoz a Magyar Honvédség Egészségügyi Központban. A kiértékelést követően, szakorvosi véleménnyel, diagnózissal kiegészítve visszaküldenék azokat. Az eszköz egyszerü megvalósíthatósága és kezelhetősége miatt zökkenőmentesen és gyorsan rendszerbe álltható.

\subsection{Otthoni gondoskodás}

Koncepcióm legvitatottabb, legképlékenyebb pontja. Az Amerikai Egyesült Államokban jelenleg is több variációját tesztelik vegyes eredményekkel, jelenleg is keresik az arany középutat a képesség funkcióinak meghatározásával. Koncepciómban jómagam feltétlenül hiszek a pozitív hozadékában, bár jelenleg egy csökkentett funkciókkal rendelkező lehetőségben gondolkodom, amely természetesen az állomány igényeinek monitorozását követően bővíthető. A képesség lényege, hogy a kapcsolat az egészségügyi ellátás és a katona között a munkaidő leteltével se szűnjön meg. Ezzel a lehetőséggel adunk egy „vékony köldökzsinórszerü" gondoskodási szálat az állománynak munkaidőn túlra is. A képesség azoknak szolgálhatna segítségül, akik kellő önkontrollal, 
egészségügyi problémabelátással rendelkeznek, és az egészségügyi problémájuk súlyát tekintve, a sürgősségi ellátást nem akarják terhelni, de egészségügyi szakembertől tanácsra (például akut tüneteknél vagy gyógyszerszedéssel kapcsolatban), e-receptre, esetleg kontrollra (például telemedicinális EKG, vérnyomás-, vércukormérés) igényt tartanának. A kiinduló gondolatom egyfajta applikáció alapú, „telefonos” chat, amely munkaidőn túli, a hivatalos ügyeleti rendszer részeként tudna funkcionálni egy zárt kör, az adott alakulat személyi állománya részére. A képességet egy android vagy IOS alapú mobiltelefonos applikáció keretében lehetne müködtetni. Első körben a chatalkalmazásban kizárólag az ügyeletet adó szakasszisztens szólítható meg, a szakasszisztens döntésének függvénye, hogy a probléma megoldásának folyamata orvos végzettségü személyig eljut-e.

\subsection{Egészségtudatos Életmód Program}

Terveim szerint, a program egy komplex egészségügyi mobiltelefonos applikáció önálló programjaként fog megvalósulni, amelyet egy későbbi értekezésemben szeretnék bemutatni. A koncepció bemutatását az egészségmagatartás definíciójával kezdem. Gochman mindazon magatartási mintákat, cselekvéseket és szokásokat érti alatta, amelyek hozzájárulnak az egészség fenntartásához, az egészség helyreállításához vagy javításához. Az egészségmagatartás hatással van a halálozások alakulására, azok okaira és a főbb megbetegedésekre, beleértve a betegségek kialakulását, illetve előrehaladását, a kezelések hatékonyságát és az életminőséget. ${ }^{17}$

\section{Egészségtudatos Életmód Program - telefonos applikáció felépítése}

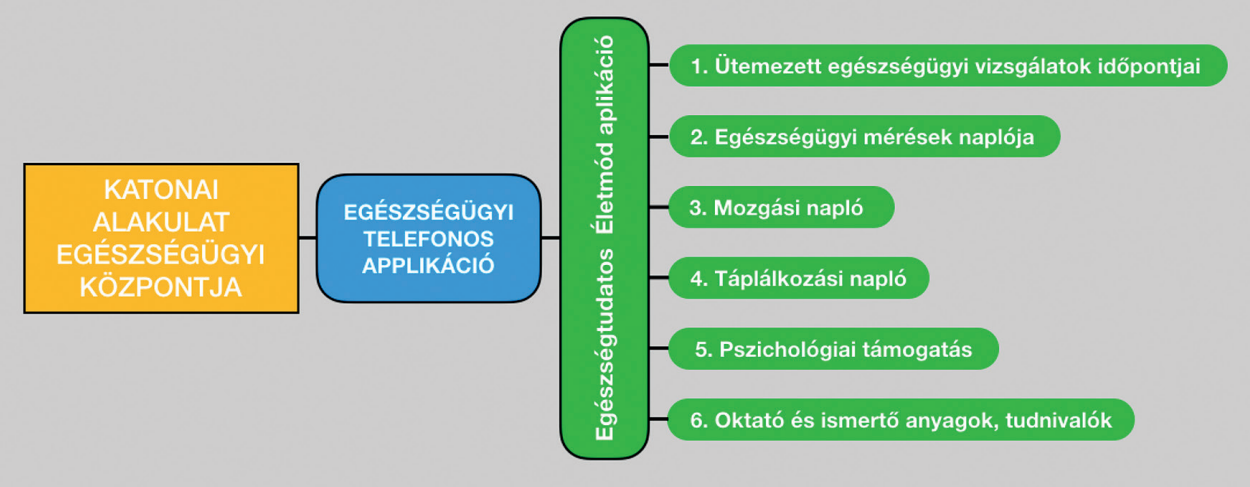

2. ábra: Egészségtudatos Életmód applikáció felépitése

Forrás: a szerző szerkesztése

Edwin B. Fisher et alii: Behavior Matters. American Journal of Preventive Medicine, 40. (2011), 5. 15-30. 
A telefonos applikáció az alábbi modulokból áll:

- Ütemezett egészségügyi vizsgálatok időpontjai;

- Egészségügyi mérések napló (vérnyomás, pulzus, vércukor, EKG, testsúly, BMI, zsír/ izom arány stb.);

- Mozgási napló (lépésszámláló, cardioedzések adatai);

- Táplálkozási napló (elfogyasztott étel és a napi bevitt kalóriamennyiség);

- Pszichológiai támogatás (személyiségfejlesztés, tesztek, relaxációk);

- Oktató és ismertető anyagok, tudnivalók,

- Elméleti háttér (tananyagok);

- Kalóriatáblázat;

- Mintaétrendek;

- Edzésminták;

- Felvilágosító információk - káros szenvedélyek.

Az Egészséges életmód Program hatékonyságának egyik kérdése, hogy az állomány, akiknek ez készülni fog, milyen fokú egészségtudatossággal rendelkezik. Az egészségtudatosságot úgy tudnám röviden definiálni, hogy az adott személy (esetünkben katona) mennyire érzi magát képesnek, kompetensnek, hogy az életminőségén, életmódján, esetleges negatív berögződésein változtatni tudjon. A KSH ide vonatkozó adatai alapján, a magyar lakosság 4/5-e úgy vélekedik, hogy tehet az egészsége érdekében. Ami némileg árnyalja a képet, hogy a kor előrehaladtával, illetve az alacsonyabb iskolai végzettségüek körében az emberekben a befolyásolási képesség hite is csökken, hogy aktívan tehet az egészsége érdekében, bár a szám nem megy $2 / 3$ alá. ${ }^{18}$

Az egészséges életmód program célja, hogy az adott alakulat állományának lehetősége legyen szakemberek által irányítottan, az egészséges életmód összetevőivel és gyakorlati lépéseivel megismerkedni, valamint szándék esetén a programban részvétellel fejlődni.

Gyakorlati megvalósulását úgy képzelem el, hogy az alakulat egészségügyi központjának orvosa és pszichológusa, valamint az alakulat személyi edzője a programba jelentkezőknek orvosi vizsgálattal és az egészségügyi állapot folyamatos monitorozásával, viselkedésterápiával, táplálkozási tanácsadással és személyi edzéssel támogatja az életmódváltást.

Az applikáció segítséget nyújt a programban részt vevő szakembereknek, hogy a résztvevők egészségügyi értékeinek változását, illetve edzés-, sportolási mennyiségeit nyomon kövesse. Napjaink okostelefonjai lehetőséget biztosítanak, hogy a személy aktivitását és napi tevékenységét automatikusan vagy manuálisan naplózhassák. Az okostelefonok képességei, szenzorai akár a program és ezzel együtt a személy pontosabban vezetett dokumentációjára is felhasználhatók. Innen egy lépés az adatok megosztása egy elöre kialakított felületen, tárhelyen, amelyről kompetencia alapján a szakszemélyzet részére hozzáférés biztosítható. 


\subsection{Oktatás, kiképzés}

A hang és kép alapú, azaz webkamerát és mikrofont magában foglaló széles sávú internetkapcsolatot használó rendszer további hasznosítási lehetőségeket is hordoz magában. Az egészségügyi állományt érintő egyes oktatási, képzési és vizsgáztatási feladatokat akár online konferenciahívással egybekötve is meg lehetne valósítani.

A rendszer alkalmas konzultációra is, ami tulajdonképpen a klasszikus távkonzílium vagy szupervízió. Az alapellátás során a diagnózisfelállítás folyamatába, a kezelés menetébe kommunikációs eszközökön keresztül távoli orvos- vagy szakszemélyzetet lehet igény esetén bevonni.

\section{5. Összefoglalás - Következtetések}

Cikkem összefoglalásaként kijelenthetö, hogy a kor munkaerőpiaci tendenciái (katonaorvos-hiány), illetve az egészségügy területén történt nagyarányú fejlődés (telemedicina megjelenése a civil egészségügyi ellátó intézményekben) következtében a csapategészségügyi ellátás eszközrendszerének fejlesztése immár sokáig nem odázható el. A Szolgálati Szabályzat katonai egészségügyi ellátást meghatározó passzusai alapján, az előírt kötelezettségek elvégzését nagymértékben megkönnyítenék a fent említett eszközök. A fent bemutatott telemedicinális eszközöket átalakítás és módosítás nélkül is alkalmasnak tartom arra, hogy azokat bevezessék a csapategészségügy eszközrendszerébe.

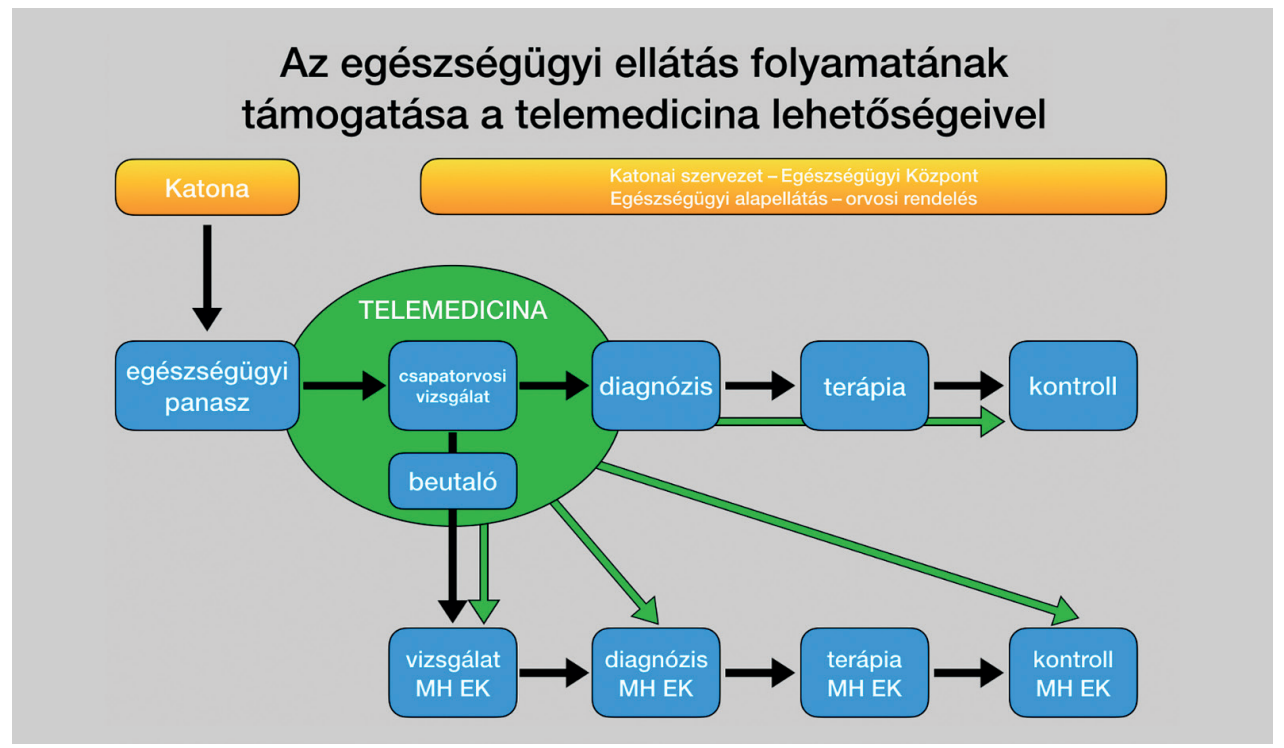

3. ábra: Az egészségügyi ellátás folyamatának támogatása a telemedicinával

Forrás: a szerző szerkesztése 
A telemedicina a távkonzílium funkciójával a diagnózis felállításának folyamatában segít, a távdiagnosztika opcionális támaszként jelen lehet a kórmeghatározásban, a távfelügyelet lehetőségét kihasználva pedig támogatja a helyben feladatot végrehajtó egészségügyi állományt és akár az otthonában lévő beteget, hogy kizárólag az indokolt esetekben utalják be a beteget magasabb ellátási szintre.

Az értekezésben megállapítottam, hogy elősegíthetik a magasabb minőségi ellátást, jelentős mértékben képesek lerövidíteni a betegutat, valamint időt takaríthatnak meg mind a páciens, mind az egészségügyi szakemberek részére. A képességek bevezetésével a régóta várt csapatszintű prevenciós lehetőségek is bővülnek.

Azonban annak érdekében, hogy a múködtetésük anomáliákat ne generáljon, indokoltnak tartom egy alapos és következetes szabályozási rendszer kialakítását. A szükséges, kialakítandó szabályzók széles spektrumot ölelnek fel, beletartozik a kiképzés terén az új képességek múködtetésére a szakasszisztensi állomány felkészítése, oktatása és kompetenciáinak meghatározása, a küldő és a fogadó oldal dokumentációs kötelezettsége, az infokommunikációs müszaki követelmények meghatározása, az adatvédelem (kibervédelem) is. Orvosi szakterületenként javaslom a szabályzását kidolgozni, hogy a telemedicinális távkonzultáció milyen esetekben müködhet, melyek azok a tünetek, tünetcsoportok, amelyeknél a beteg fizikai jelenléte és vizsgálata elkerülhetetlen.

A jövőre nézve, pszichológiai szempontból, a telemedicinális eszközök hosszú távú igénybevétele során két lehetséges rizikófaktorra szeretném még felhívni a figyelmet. Az egyik lehetséges jelenség, hogy az orvos-beteg kapcsolat a gazdag, több szálon futó érzelmi, informális tartalmából veszíthet, következésképpen elszemélytelenedhet. Mivel a kapcsolatot egy monitor és mikrofon tartja fenn, az emberekben (mind az ellátó, mind az ellátandó oldal részéről) megvan a hajlam, hogy a telekommunikációs kapcsolatban lévő „kötelezettségeit” (például udvariasság, türelem, korrektség) hanyagabbul kezelje, mint egy személyes, élő szituációban, mivel egyesek abban a hiedelemben vannak, hogy a távolság a kommunikációs normáktól eltérő viselkedés egyes következményeitől „megvédi”. Ennek kiküszöbölésére kommunikációs tréning és protokollanyag összeállítását javaslom.

A másik lehetséges veszélyforrásnak tartom, hogy az ellátott személy és/vagy a konzultációban részt vevő szakasszisztens egyes esetekben a távkonzultáció instrukcióit - egyeztetés nélkül - megmásítja, torzítja, illetve a telemedicinális kapcsolat esetleges elszemélytelenedésének következményeként a gyógyulási folyamatot saját kézbe veszi vagy saját eredményének címkézi. Ez a folyamat oktatással, felkészítéssel szintén kiküszöbölhető.

A tervezett bevezetendő telemedicinális képességek nemcsak magasabb szintü ellátást biztosítanak, hanem egyfajta szűrőhatást fejtenek ki, hiszen amennyiben csapategészségügyi szinten a katona egészségügyi problémáját kezelni lehet, ezzel egyúttal tehermentesülhet a Magyar Honvédség Egészségügyi Központ. 


\section{Felhasznált irodalom}

Baranyai Gábor: Ösztöndíjjal enyhítik a katonaorvos-hiányt. Magyar Idők, 2017. Online: https://magyaridok.hu/belfold/osztondijjal-enyhitik-katonaorvos-hianyt-1369249/

Bágyi Péter - Mohai Viktor: (Táv)leletezés és munkamenedzsment. Interdiszciplináris Magyar Egészségügy, 13. (2014), 6. Online: www.researchgate.net/profile/ Peter_Bagyi/publication/270886593_Tavleletezes_es_munkamenedzsment/ links/54b797b80cf24eb34f6ebc98.pdf

Bán Attila: A telemedicina potenciális szerepe a háziorvosi ellátás hozzáférhetőségének és minőségének javitásában. Magyar Tudományos Akadémia, Közgazdaság- és Regionális Tudományi Kutatóközpont. é. n. Online: https://doi.org/10.18427/ iri-2017-0109

Bogner Péter - Bágyi Péter: A teleradiológia alkalmazása hazánkban. Magyar Orvos, (2009), 10. 43-46. Online: https://weborvos.hu/adat/files/avera/mo4346.pdf

Danis Judit - Forczek Erzsébet - Bari Ferenc: A telemedicina alkalmazása a bőrgyógyászatban: a teledermatológia. Orvosi Hetilap, 157. (2016), 10. 363-369. Online: https://doi.org/10.1556/650.2016.30371

Fejes Zsolt: Új lehetőség a védelem-egészségügyi ellátásban: Telemedicina. Hadmérnök, 11. (2016), 1. 233-239.

Fisher, Edwin B. - Marian L. Fitzgibbon - Russel. E. Glasgow - Debra Haire-Joshu - Laura L. Hayman - Robert M. Kaplan - Marilyn S. Nanney - Judith K. Ockene: Behavior Matters. American Journal of Preventive Medicine, 40. (2011), 5. 15-30. Online: https://doi.org/10.1016/j.amepre.2010.12.031

Gochman, David S.: Handbook of Health Behavior Research. NewYork, Plenum Press, 1997. Online: https://doi.org/10.1007/978-1-4899-0484-3

Jasztrab Jácint Szilárd: A katonaorvosi pályaválasztás és pályaelhagyás motivációi. Honvédségi Szemle, 146. (2018), 2. 101-113.

Kiss István - Kékes Ede: A hypertóniás betegek célvérnyomás-elérési arányának és gondozási minőségének segítése telemedicinális lehetőségek alkalmazásával. Online: https://elitmed.hu/kiadvanyaink/hypertonia-es-nephrologia/a-hypertonias-betegek-celvernyomas-eleresi-aranyanak-es-gondozasi-minosegenek-segitese-telemedicinalis-lehetosegek-alkalmazasaval

Tóth Anikó Panna: A mentálhigiéné fejlesztési lehetőségei a telemedicina segítségével. Metszetek, 6 (2017), 2. 139-166.

Wood, Megan: Telemedicine continues to gain traction in the healthcare industry, offering a convenient, integrated experience for patients. Becker's Hospital Review, 2016. Online: www.beckershospitalreview.com/healthcare-information-technology/telemedicine-to-attract-7m-patient-users-by-2018-12-statistics-on-thethriving-market.html

\section{Jogi forrás}

24/2005. (VI. 30.) HM rendelet a Magyar Honvédség Szolgálati Szabályzatának kiadásáról 


\section{Internetes források}

Állami Egészségügyi Ellátóközpont: Telemedicina. Egészségtudományi fogalomtár, é. n. Online: https://fogalomtar.aeek.hu/index.php/Telemedicina

Becker's Health It: Telemedicine to attract 7M patient users by $2018-12$ statistics ont he thriving market - 2018. Online: www.beckershospitalreview.com/healthcare-information-technology/telemedicine-to-attract-7m-patient-users-by-201812-statistics-on-the-thriving-market.html

Központi Statisztikai Hivatal: 1.1. Népesség, népmozgalom (1900-) 3/3. Online: www. ksh.hu/docs/hun/xstadat/xstadat_hosszu/h_wdsd001c.html

Központi Statisztikai Hivatal: A 2014-ben végrehajtott Európai lakossági egészségfelmérés eredményei - összefoglaló adatok. 2018. Online: www.ksh.hu/docs/hun/ xftp/idoszaki/elef/elef2014_osszefoglalo.pdf 